\title{
Process upsets in a full-scale anaerobic digestion bioreactor: over-acidification and foam formation during biogas production
}

\author{
Lucie Moeller (i) and Andreas Zehnsdorf
}

\begin{abstract}
Background: Biogas plays a worthwhile role as a renewable, storable energy source. Anaerobic digestion (AD) is the core process in biogas production. The two most common process upsets that occur during this biotechnological process in practice are over-acidification and foam formation. Several research projects have been carried out so far to identify the causes of these upsets and to develop early warning indicators. However, the relevant laboratory results have not yet been verified in practice. Accordingly, the aim of this work was to study the practical application of the published tools in the case of a full-scale biogas plant.

Methods: A full-scale AD plant utilizing cattle manure and energy crops was sampled over a period of 12 weeks. During this time, over-acidification and foam formation occurred in the primary digester.

Results: The sum of acetate, propionate and butyrate (VFA $)$ and the ratios of VFA $A_{S}$ to magnesium (VFA $/ \mathrm{Mg}$ ), calcium $\left(V F A_{S} / C a\right)$, and phosphorus (VFAs/P) were found to be good predictive tools to identify over-acidification for the given AD system. Their values increased by factors of 6 (VFAs/Mg and VFA $/ \mathrm{Ca}$ ) and 13 (VFAs, VFAs/P) in the early overacidification phase. In contrast, the VFATIC ratio, which is a common indicator in practice, increased only by a factor of 2 during this phase. An ammonium-nitrate-urea solution proved to be an effective agent for foam suppression when sugar beet was used as a substrate. Its application showed no negative effect on the daily electricity production and the achieved long-term foam elimination.

Conclusions: Several parameters were verified to be able to serve as an early warning indicator of over-acidification, but not one was found to be able to serve as an early warning indicator of foam formation in AD. Further research is needed to identify parameters with predictive potential for indicating foaming in AD.
\end{abstract}

Keywords: Anaerobic digestion, Biogas, Over-acidification, Foaming, Process upsets, Full-scale

\section{Background}

Anaerobic digestion (AD) is a commonly used process for the utilization of biogenic material for energy production. Knowledge of the microbial process for the anaerobic digestion has increased considerably in recent years. However, there are issues still remaining unclear. The most common upsets of the biogas process are over-acidification [1] as well as the formation of foam [2] and floating layers [3].

Over-acidification is an upset of the $\mathrm{AD}$ process characterized by a decline in digestate $\mathrm{pH}$ due to the

\footnotetext{
* Correspondence: lucie.moeller@ufz.de

Centre for Environmental Biotechnology, UFZ_-Helmholtz Centre for

Environmental Research GmbH, Permoserstrasse 15, 04318 Leipzig, Germany
}

accumulation of fatty acids as a consequence of a disturbed methanogenesis step. Over-acidification occurs mainly as a result of an overload of the biogas system due to either high organic loading rates $[1,4]$ or the occurrence of inhibitors in the digester such as ammonia, sulfide, heavy metals, or substituted phenolic compounds [5-7].

The formation of foam may also occur as a consequence of high organic loading rates [8]. Furthermore, the use of some substrates such as grain [9], sugar beet [10-12], or yeast [2] can even in relatively small amounts lead to foam formation.

The consequences of these process upsets are financial losses due to the reduced biogas yield [13] as well as the 
increased deployment of staff and costs for anti-foaming agents [14]. In addition, the roof of the digester can develop leaks or be damaged if foaming occurs [2].

Research activities in the field of AD process upsets have mainly concentrated on the development of upsetprevention strategies. With regard to foam formation, a test set for the estimation of the foaming tendency of substrates [15] has been developed recently. Several abiotic factors were identified to be able to serve as early warning indicators (EWIs) for over-acidification: the total or individual concentration of volatile fatty acids (VFA) [16], the propionic/acetic acid ratio [4], the VFA/ alkalinity ratio (also known as VFA/TIC) $[17,18]$, the VFA/Ca ratio, the phosphate concentration, the $\mathrm{PO}_{4} / \mathrm{Ca}$ ratio [1], phenylacetic acid [19], as well as biogas production [16] and biogas composition, especially the $\mathrm{CH}_{4}$ yield [20] and hydrogen concentration [21].

All of these studies are primarily based on research conducted in laboratory-scale biogas digesters under well-defined conditions.

The aim of this work is to apply the experimental data to a full-scale system. For this reason, a full-scale anaerobic digester that was fed with a mixture of cattle manure, maize and grass silage, sugar beet, and coarse grain was sampled for a period of 12 weeks. During the sampling period, two process upsets occurred: overacidification and the formation of foam. The electricity production rate (that corresponds to the biogas production) and the methane and hydrogen sulfide contents in the biogas were measured on-site. During weekly sampling, various off-site abiotic parameters were determined in order to understand the course of the process upset development and to apply the EWIs under real operational conditions.

\section{Methods}

\section{General characteristics of the AD plant}

An AD plant close to Leipzig was sampled once a week for 6 weeks. This AD plant was briefly introduced in [12].

The AD plant went into operation in 2006 and is used for the digestion of cattle manure from a dairy farm with co-digestion of energy crops. It has an installed electrical power of $540 \mathrm{~kW}_{\mathrm{el}}$. The AD plant consists of one digester with a volume of $1800 \mathrm{~m}^{3}$, one secondary digester with a volume of $2200 \mathrm{~m}^{3}$ and two digestate storage tanks with volumes of $4000 \mathrm{~m}^{3}$ each. The gas storage in the roofs of the digesters was designed for $6000 \mathrm{~m}^{3}$ of biogas. Agitation in the primary digester is carried out by a horizontal paddle agitator and a submersible mixer. The secondary digester is mixed using two submersible mixers. The biogas is transformed into energy in two combined heat and power ( $\mathrm{CHP}$ ) units that combust the biogas, which was produced in both digesters. As no biogas volume was measured onsite, the daily $\mathrm{CHP}$ output was used as a parameter that depends on the daily biogas production and, thus, demonstrates the changes in microbial activity. The methane and hydrogen sulfide contents of the biogas are measured continuously using an SSM 6000 LT biogas analyzer (Pronova, Germany).

Wet fermentation is operated at $40{ }^{\circ} \mathrm{C}$. The annual substrate input is $20,000 \mathrm{t}$. The average substrate hydraulic retention time in the two digesters reaches 80 days ( 35 days for the primary and 45 days for secondary digester). The obtained organic loading rate is $4-5 \mathrm{~kg} \mathrm{VS} \mathrm{m}^{-3}$ days $^{-1}$. The substrate mix consists of cow manure $(55 \%$ w/w fresh mass), maize silage ( $19 \% \mathrm{w} / \mathrm{w}$ fresh mass), and-on a seasonal basis-sugar beet ( $15 \% \mathrm{w} / \mathrm{w}$ fresh mass), grass silage ( $4 \% \mathrm{w} / \mathrm{w}$ fresh mass), coarse grain $(2 \% \mathrm{w} / \mathrm{w}$ fresh mass), and residual fodder ( $2 \% \mathrm{w} / \mathrm{w}$ fresh mass). The digester is loaded once per hour. The agitation cycle in the digester is $6 \mathrm{~min}$ per hour during stable operation and is continuous during the foaming periods. The characteristics of the digestates from the primary and secondary digesters in stable operation are shown in Table 1.

\section{Characteristics of the AD plant operation during the monitoring period}

The biogas plant suffered from two kinds of process imbalances during the monitoring period from September 2014 to February 2015 (i.e., 158 days): foam formation on two occasions and one over-acidification phase. No digestate samples were collected during the first foaming phase. Sampling was started on day 81 of the monitoring period and lasted for 12 weeks until day 158. This time span was further split into two time periods: the process upset period (from the very beginning until day 123) and the period of stable operation (days 124 to 158).

The substrate input during the process upset period is shown in Fig. 1. The first foaming event lasted from the start of sugar beet co-digestion at the beginning of the monitoring period until day 54. Based on previous research results concerning foam formation, in the case of sugar beet substrate use [12], a reduction of foam was

Table 1 Analytical data of the digestates from the primary and secondary digesters during stable operation $(n=5)$

\begin{tabular}{lll}
\hline & Primary digester & Secondary digester \\
\hline TS (\%) & $6.34 \pm 0.54$ & $4.98 \pm 0.60$ \\
VS (\% TS) & $74.2 \pm 0.53$ & $68.2 \pm 0.75$ \\
$\mathrm{pH}(-)$ & $7.80 \pm 0.15$ & $7.93 \pm 0.14$ \\
$\mathrm{VFA} / \mathrm{TIC}(-)$ & $0.19 \pm 0.01$ & $0.16 \pm 0.01$ \\
$\mathrm{NH}_{4}-\mathrm{N}(\mathrm{g} / \mathrm{L})$ & $1.131 \pm 153$ & $1.680 \pm 201$ \\
Acetate $(\mathrm{mg} / \mathrm{L})$ & $126 \pm 49.2$ & $12.1 \pm 11.8$ \\
Propionate $(\mathrm{mg} / \mathrm{L})$ & $24 \pm 5.76$ & $10.7 \pm 10.2$ \\
Butyrate $(\mathrm{mg} / \mathrm{L})$ & $<1$ & $<1$ \\
\hline
\end{tabular}



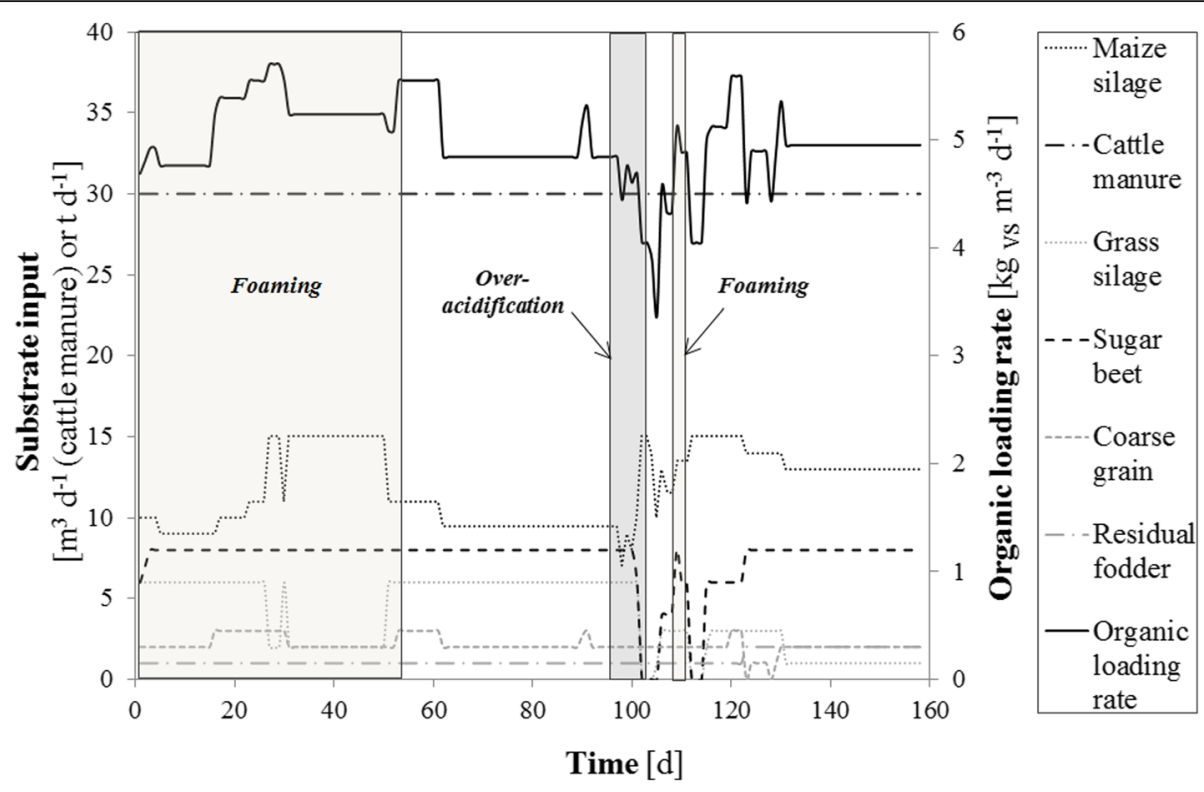

Fig. 1 Substrate input into the primary digester and organic loading rate during the process upset period

also monitored in a long-term manner upon the addition of $100 \mathrm{~L}$ of an ammonium-nitrate-urea (ANU) solution (Piasan, Germany). This agent contained $28 \%$ nitrogen and is commonly used in agriculture as a fertilizer. During the foaming period, continuous agitation was carried out in the primary fermenter in order to stir in the foam. Two days after ANU addition, the foam disappeared and the stirring period was changed to 6 min per hour. The second foaming period occurred on days 108 and 109 when the foam was again suppressed by the addition of $100 \mathrm{~L}$ of ANU.

Over-acidification occurred in the primary digester from days 95 to 104 . As a countermeasure, a part of the digestate from the secondary digester was pumped into the primary digester on the 96th day. The cause of overacidification was identified by the biogas plant operator as being the feeding of a charge of moldy sugar beet, where as a result the loading of grass silage and sugar beet was stopped for 4 days from days 102 to 105 . By the way, the grass silage was of poor quality. Therefore, the maize silage input was increased by one third, in order to maintain biogas production.

Furthermore, three technical accidents happened during the process upset period. On day 60 , one CHP unit overheated during maintenance of the second CHP unit. On days 106 and 107, only partial loading of the CHP units was possible due to a transformer fuse, whereas from the 112th to the 114th day, the powder disperser was out of order and as a result no sugar beet loading was possible.

\section{Digestate analyses}

Samples of digestate were taken once a week in the period from days 81 to 158 and transported to the laboratory immediately. The samples were then frozen at $-18{ }^{\circ} \mathrm{C}$ and defrosted immediately prior to the analysis. The methods used for analysis are summarized in Table 2. The samples were pre-treated in order to guarantee a sufficient homogeneity for the analyses. The sample was passed through a sieve with a mesh size of $0.75 \mathrm{~mm}$. The sieved sample was then centrifuged (20 min, at $5300 \mathrm{rpm}$ and $20{ }^{\circ} \mathrm{C}$, Avanti 30 Centrifuge, Beckman, Brea, USA) and filtered (SM 16249 pressure filtration device, Sartorius, Göttingen, Germany; nylon membrane filter: pore size $0.45 \mu \mathrm{m}$, Whatman, Germany).

\section{Results}

\section{Variables measured on-site during the process upsets}

The biogas quantity (expressed as the daily CHP output) and quality (methane and hydrogen sulfide $\left(\mathrm{H}_{2} \mathrm{~S}\right)$ contents) during the process upset period are shown in Fig. 2.

On day 54, $100 \mathrm{~L}$ of ANU solution was added to the primary digester for the first time. After 2 days, the foam layer in the primary digester has disappeared. Interestingly, ANU addition had no effect on either biogas production or the methane content in the biogas. The average daily CHP output was found to be $13.1 \pm 0.6$ $\mathrm{MWh} /$ day and $13.5 \pm 0.2 \mathrm{MWh} /$ day 6 days prior to ANU addition and 6 days after ANU addition, respectively. The drop in electricity production on day 61 was caused 
Table 2 Analytical methods for wet chemical analyses of the digestate

\begin{tabular}{|c|c|c|}
\hline Parameter & Sample pre-treatment & Analytical methods and instruments \\
\hline TS & No & DIN 12880 \\
\hline VS & No & DIN 12879 \\
\hline $\mathrm{pH}$ value & Sieved & Microprocessor pH meter pH 95 (WTW, Germany) \\
\hline VFA/TIC & Sieved & Titration method according to [18] \\
\hline TOC, TN & Sieved & TOC-VCSH/CSN with a TN unit (Shimadzu, Japan) \\
\hline $\mathrm{NH}_{4}-\mathrm{N}$ & Filtered & $\begin{array}{l}\text { DIN } 38406 \text { E5. Spektroquant }{ }^{\oplus} \text { test kit (measuring range } 0.01-3 \mathrm{mg} \\
\mathrm{L}^{-1} \mathrm{NH}_{4}-\mathrm{N} \text {, Merck. Germany). photometric measurement with } \\
\text { MultiLab P5 (WTW, Weilheim, Germany) }\end{array}$ \\
\hline Acetate, propionate, butyrate, lactate & Filtered & $\begin{array}{l}\text { High-performance liquid chromatography (Shimadzu, Japan); } \\
\text { detector: } \mathrm{RID}-10 \mathrm{~A} \text {; column: VA 300/7.8 Nucleogel Ion } 300 \mathrm{OA} \text {; } \\
\text { eluent: } 0.01 \mathrm{~N} \mathrm{H}_{2} \mathrm{SO}_{4}\end{array}$ \\
\hline Water-soluble elements (Ca, Mg, P, S, K, Na) & Filtered & $\begin{array}{l}\text { Inductively coupled plasma atomic emission spectrometry ICP-AES } \\
\text { (Spectroflame, Spectro Int., Kleve, Germany) }\end{array}$ \\
\hline
\end{tabular}

by a defect in the CHP units as described in the "Characteristics of the AD plant operation during the monitoring period" section and had no relation to the biogas process itself. The biogas contained $51.9 \pm 0.5 \%$ methane prior to ANU addition and $52.5 \pm 0.2 \%$ methane thereafter. The concentration of hydrogen sulfide showed a decreasing trend after ANU addition. The fermenter content surface remained normal until the resumption of sugar beet feeding after the break due to over-acidification.

As a consequence of over-acidification, daily electricity production halved from $13.5 \mathrm{MWh}$ /day to $6.9 \mathrm{MWh}$ /day during just 2 days from the 95th to the 97th day. The pumping of the digestate from the secondary digester to the primary digester caused a temporary improvement in daily electricity production, and $10.9 \mathrm{MWh}$ /day were produced on day 101. Nevertheless, there was a further deterioration in CHP output during the following day, resulting in the biogas plant operator's decision to change the substrate mix by discontinuing the feeding of sugar beet and grass silage (Fig. 1). This measure ultimately led to a complete recovery of the system after 4 days.

The methane concentration in the biogas dropped from values of $53 \%$ before the process upset down to $45.5 \%$ on day 96. The $\mathrm{H}_{2} \mathrm{~S}$ content reached its maximum value of $688 \mathrm{ppm}$ at the same time. Over the course of the overacidification event, the methane concentrations changed

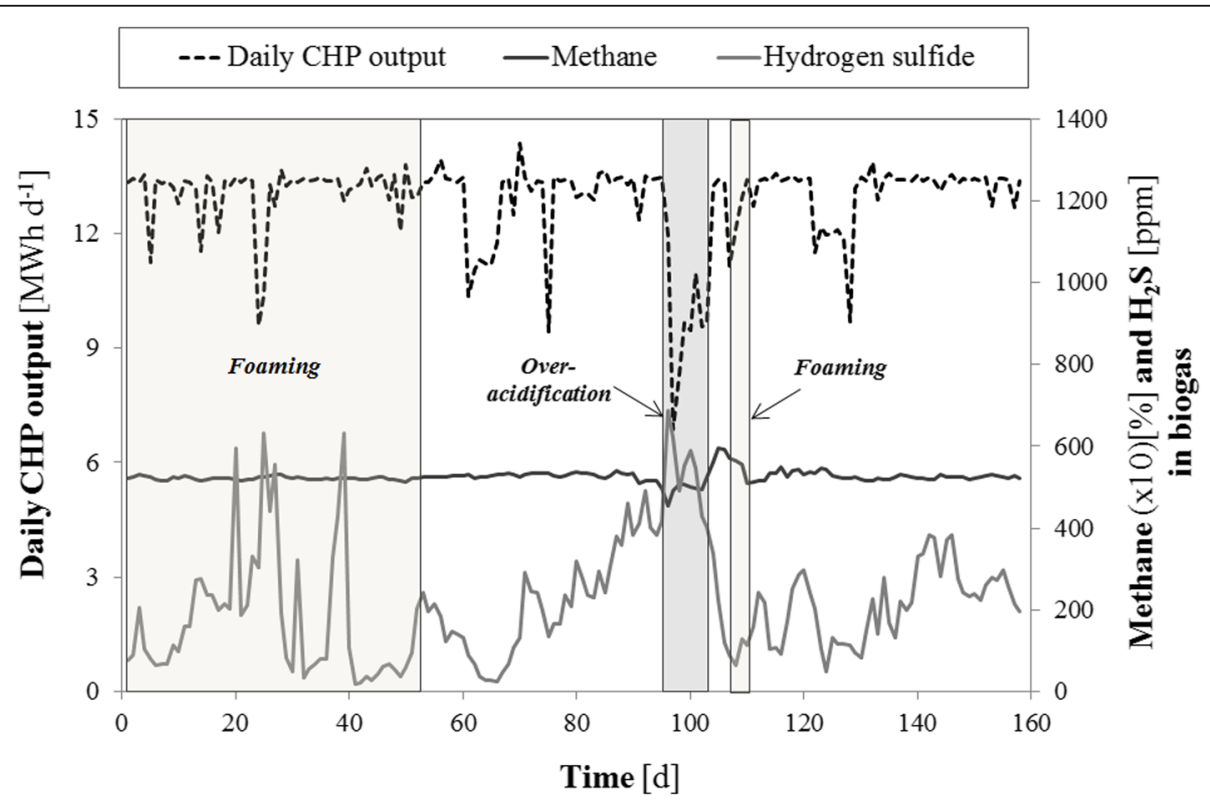

Fig. 2 Quality of biogas produced in the biogas plant during the process upset period. Daily output of combined heat and power (CHP) units as well as methane and hydrogen sulfide $\left(\mathrm{H}_{2} \mathrm{~S}\right)$ contents in the biogas 
to values of $50 \%$ and the $\mathrm{H}_{2} \mathrm{~S}$ concentration dropped again to $490 \mathrm{ppm}$. After the substrate mix was changed, the methane concentration gradually increased to $59.5 \%$ on day 105.

The $\mathrm{H}_{2} \mathrm{~S}$ concentration continued its descending trend until day 108, when the next process upset occurred: the reintroduction of sugar beet into the substrate mixture (Fig. 1) caused foaming in the primary digester. The $30 \mathrm{~cm}$ foam layer disappeared after ANU addition. The $\mathrm{H}_{2} \mathrm{~S}$ concentration increased slightly after the foaming period, although it was still lower than during the stable period before over-acidification. The methane concentration decreased after the foaming period by $6 \%$ from 57 to $51 \%$ and remained stable for 3 days. Thereafter, the methane content increased again to $53.5 \%$ and remained at this level until the end of the first sampling period.

After repeated ANU addition, no foam was observed up to the end of the period of sugar beet co-digestion during the final days of the monitoring period.

\section{Analytical data during the process upsets}

The analytical data of the samples from the primary digester before, during and after the over-acidification and the second foaming period are shown in Tables 3, 4, and 5 . The VFA showed an increasing tendency from the very beginning of sampling (Table 3 ). The VFA/TIC ratio rose from 0.13 to 0.17 during this time (Table 3) and reached its maximum value of 1.69 on day 102 . Due to the effective countermeasures that were implemented by the biogas plant operator (starvation diet and pumping of a part of the digestate from the secondary digester to the primary digester), the VFA/TIC ratio dropped rapidly to 0.41 week later. In this time, foam formation occurred in the primary

Table $3 \mathrm{pH}$ value, ammonium-nitrogen $\left(\mathrm{NH}_{4}-\mathrm{N}\right)$, VFA/TIC, TOC, and TN of digestates from the primary digester

\begin{tabular}{llllllll}
\hline Time (d) & $\mathrm{pH}$ & $\begin{array}{l}\mathrm{VFA} \\
(\mathrm{mg} / \mathrm{L})\end{array}$ & $\begin{array}{l}\mathrm{TIC} \\
(\mathrm{mg} / \mathrm{L})\end{array}$ & $\begin{array}{l}\mathrm{VFA} / \mathrm{TIC} \\
(-)\end{array}$ & $\begin{array}{l}\mathrm{TOC} \\
(\mathrm{mg} / \mathrm{L})\end{array}$ & $\begin{array}{l}\mathrm{TN} \\
(\mathrm{mg} / \mathrm{L})\end{array}$ & $\begin{array}{l}\mathrm{NH}_{4}-\mathrm{N} \\
(\mathrm{mg} / \mathrm{L})\end{array}$ \\
\hline 81 & 7.90 & 1606 & 12,073 & 0.13 & 19,570 & 4570 & 1550 \\
88 & 7.94 & 1871 & 11,073 & 0.17 & 16,652 & 4144 & 1316 \\
95 & 8.05 & 3311 & 10,179 & 0.33 & 17,710 & 4270 & 1230 \\
$\mathbf{1 0 2}$ & $\mathbf{7 . 0 3}$ & $\mathbf{9 1 9 6}$ & $\mathbf{5 4 4 1}$ & $\mathbf{1 . 6 9}$ & $\mathbf{2 1 , 3 1 6}$ & $\mathbf{4 2 7 3}$ & $\mathbf{1 4 8 3}$ \\
$\mathbf{1 0 9}$ & $\mathbf{8 . 0 9}$ & $\mathbf{4 0 3 4}$ & $\mathbf{1 0 , 8 6 1}$ & $\mathbf{0 . 3 7}$ & $\mathbf{1 8 , 6 1 0}$ & $\mathbf{4 2 3 3}$ & $\mathbf{1 4 9 4}$ \\
116 & 8.19 & 3731 & 9,485 & 0.39 & 17,055 & 4169 & 1198 \\
123 & 7.91 & 2154 & 11,815 & 0.18 & 15,914 & 3784 & 1080 \\
130 & 7.99 & 1627 & 9,005 & 0.18 & 18,148 & 4312 & 1541 \\
137 & 7.73 & 2133 & 10,814 & 0.20 & 17,996 & 4422 & 1261 \\
144 & 7.93 & 1884 & 10,440 & 0.18 & 16,700 & 4064 & 1217 \\
151 & 7.70 & 2017 & 11,525 & 0.18 & 17,689 & 4297 & 1443 \\
158 & 7.64 & 2291 & 10,906 & 0.21 & 10,490 & 3433 & 1194 \\
\hline
\end{tabular}

The data from the over-acidification period are marked in bold and those from the foaming period in bold and italics
Table 4 Concentrations of organic acids in the digestates from the primary digester

\begin{tabular}{llllll}
\hline Time $(\mathrm{d})$ & $\begin{array}{l}\text { Acetate } \\
(\mathrm{mg} / \mathrm{L})\end{array}$ & $\begin{array}{l}\text { Propionate } \\
(\mathrm{mg} / \mathrm{L})\end{array}$ & $\begin{array}{l}\text { Butyrate } \\
(\mathrm{mg} / \mathrm{L})\end{array}$ & $\begin{array}{l}\text { Lactate } \\
(\mathrm{mg} / \mathrm{L})\end{array}$ & $\begin{array}{l}\mathrm{VFA}_{\mathrm{S}}(\text { (EAcProBut) } \\
(\mathrm{mg} / \mathrm{L})\end{array}$ \\
\hline 81 & 19.8 & $<1$ & $<1$ & 13.0 & 19.8 \\
88 & 130 & 27.0 & $<1$ & $<1$ & 157 \\
95 & 2023 & 85.2 & 38.0 & $<1$ & 2,146 \\
$\mathbf{1 0 2}$ & $\mathbf{8 8 2 7}$ & $\mathbf{6 5 5}$ & $\mathbf{6 0 2}$ & $<1$ & $\mathbf{1 0 , 0 8 4}$ \\
$\mathbf{1 0 9}$ & $\mathbf{2 5 8 6}$ & $\mathbf{1 1 9}$ & $\mathbf{4 4 . 3}$ & $\mathbf{2 7 . 8}$ & $\mathbf{2 7 4 9}$ \\
116 & 2832 & 61.0 & 24.2 & 30.5 & 2917 \\
123 & 295 & 18.7 & $<1$ & 30.0 & 314 \\
130 & 119 & 26.4 & $<1$ & 60.0 & 145 \\
137 & 149 & 32.4 & $<1$ & 53.8 & 181 \\
144 & 88 & 17.2 & $<1$ & 52.3 & 105 \\
151 & 77 & 20.9 & $<1$ & 30.6 & 98.0 \\
158 & 199 & 23.0 & $<1$ & 69.1 & 222 \\
\hline
\end{tabular}

The data from the over-acidification period are marked in bold and those from the foaming period in bold and italics

digester. Three weeks after over-acidification, the VFA/ TIC ratio dropped again to 0.2 and remained at this level until the end of the sampling period. In the secondary digester, the VFA/TIC ratio was stable at $0.15 \pm 0.02$ during the entire sampling time.

The $\mathrm{pH}$ value was stable during the first three weeks of sampling at $7.96 \pm 0.07$ and decreased to 7.03 only at the time of the most intensive over-acidification on day 102 (Table 3). One week later, during foam formation, the $\mathrm{pH}$ value of 8.1 was again within its normal range. In the next sample, the $\mathrm{pH}$ further increased to 8.2, dropping to a value of 7.9 and remaining stable at values

Table 5 Concentrations of water-soluble elements in the samples of the digestates from the primary digester

\begin{tabular}{lllcccc}
\hline $\begin{array}{l}\text { Time } \\
(\text { days })\end{array}$ & $\begin{array}{l}\text { Calcium } \\
(\mathrm{mg} / \mathrm{L})\end{array}$ & $\begin{array}{l}\text { Magnesium } \\
(\mathrm{mg} / \mathrm{L})\end{array}$ & $\begin{array}{l}\text { Phosphorus } \\
(\mathrm{mg} / \mathrm{L})\end{array}$ & $\begin{array}{l}\text { Sulfur } \\
(\mathrm{mg} / \mathrm{L})\end{array}$ & $\begin{array}{l}\text { Potassium } \\
(\mathrm{mg} / \mathrm{L})\end{array}$ & $\begin{array}{l}\text { Sodium } \\
(\mathrm{mg} / \mathrm{L})\end{array}$ \\
\hline 81 & 218 & 210 & 20.5 & 33.6 & 3270 & 258 \\
88 & 243 & 269 & 12.2 & 34.0 & 3230 & 273 \\
95 & 212 & 217 & 37.9 & 47.0 & 2980 & 252 \\
$\mathbf{1 0 2}$ & $\mathbf{4 2 5}$ & $\mathbf{3 4 3}$ & $\mathbf{4 1 . 7}$ & $\mathbf{3 9 . 1}$ & $\mathbf{3 1 1 0}$ & $\mathbf{2 7 0}$ \\
109 & $\mathbf{1 4 9}$ & $\mathbf{1 5 7}$ & $\mathbf{4 0 . 4}$ & $\mathbf{4 2 . 6}$ & $\mathbf{3 1 7 0}$ & $\mathbf{2 3 1}$ \\
116 & 92.0 & 89.5 & 27.9 & 41.1 & 2510 & 199 \\
123 & 91.7 & 134 & 44.6 & 42.9 & 2870 & 215 \\
130 & 167 & 281 & 53.4 & 62.5 & 4630 & 357 \\
137 & 161 & 173 & 54.8 & 47.2 & 2860 & 250 \\
144 & 83.5 & 112 & 42.8 & 44.0 & 3470 & 238 \\
151 & 123 & 169 & 37.9 & 40.4 & 3630 & 252 \\
158 & 127 & 145 & 52.9 & 40.0 & 3220 & 228 \\
\hline
\end{tabular}

The data from the over-acidification period are marked in bold and those from the foaming period in bold and italics 
of $7.80 \pm 0.15$ until the end of sampling. In the secondary digester, the $\mathrm{pH}$ value was never lower than 7.8 during the entire sampling time.

The alkalinity (TIC) displayed a slightly declining tendency during the first 3 weeks, showing a rapid reduction of almost one half during over-acidification from values of $10-12$ to $5.4 \mathrm{~g} / \mathrm{L}$ (Table 3 ). In the post-acidification phase, the TIC values rapidly returned to the values present before the process upset. In the secondary digester, the alkalinity was stable at $12.7 \pm 1.07 \mathrm{~g} / \mathrm{L}$ during the sampling period and showed no large variations.

The organic carbon concentration (TOC) reached its highest value of $21.3 \mathrm{~g} / \mathrm{L}$ during over-acidification (Table 3). In the weeks thereafter, this value gradually dropped to $16 \mathrm{~g} / \mathrm{L}$ and remained stable at this value until the end of sampling. The TOC concentration in the secondary digester of $15.1 \pm 1.86$ was somewhat lower than in the primary digester due to the conversion of carbon to methane in the primary digester. The nitrogen concentration (TN) in both digesters remained virtually stable during the sampling period (primary digester $4.16 \pm 0.30 \mathrm{~g} / \mathrm{L}$, secondary digester $4.52 \pm 0.44 \mathrm{~g} / \mathrm{L}$ ). The TN concentration was higher in the secondary digester compared to the primary digester, as was also the case for ammonium-nitrogen (primary digester $1.33 \pm$ $0.16 \mathrm{~g} / \mathrm{L}$, secondary digester $1.65 \pm 0.21 \mathrm{~g} / \mathrm{L}$ ).

The acetate concentration increased during the first two sampling weeks from 20 to $130 \mathrm{mg} / \mathrm{L}$, while propionate appeared in the VFA spectrum in the second sample, but was below the detection limit in the first sample (Table 4). Over the further course of AD, all concentrations of single $\mathrm{VFA}_{S}$ increased significantly: acetate reached $8.8 \mathrm{~g} / \mathrm{L}$, propionate $0.65 \mathrm{~g} / \mathrm{L}$, and butyrate $0.60 \mathrm{~g} / \mathrm{L}$ on day 102 . As a result of the countermeasures that were implemented, the acetate concentration decreased again by $70 \%$ to $2.6 \mathrm{~g} / \mathrm{L}$ on the 109 th day and by a further $90 \%$ in the period from day 116 to 123 . The acetate concentration remained at low values of $21.2 \pm 16.4 \mathrm{mg} / \mathrm{L}$ during the entire sampling period in the secondary digester. Propionate appeared in the secondary digester on day 102 at a very low concentration $(15.3 \mathrm{mg} / \mathrm{L})$. Its content rose slightly in the next sample due to the addition of acidified material from the primary digester. In the remaining samples, the propionate concentration was below the detection limit in the secondary digester. No butyrate was detected in the secondary digester at any time.

The concentration of lactate had the opposite tendency to that of acetate, propionate and butyrate; its concentration was considerably lower and, in some cases, below the detection limit during over-acidification when compared with the remaining samples (Table 4).

The concentrations of calcium and magnesium reached their highest values at the 102nd day during the over-acidification phase (Table 5). The sulfur concentration had already reached its maximum 1 week before over-acidification, i.e., during the early over-acidification phase. The phosphorus concentration increased first during the acidification phase from 20 to $42 \mathrm{mg} / \mathrm{L}$, and decreased thereafter until day 116. During the stable period, the phosphorus concentration reached a maximum of $53 \mathrm{mg} / \mathrm{L}$. The potassium concentration first decreased until day 95, and then showed an increasing tendency again during the over-acidification phase. The sodium concentration fluctuated between 0.25 and $0.27 \mathrm{~g} / \mathrm{L}$ at first, and then showed a declining tendency after the process upset, falling to $0.2 \mathrm{~g} / \mathrm{L}$ on day 116 .

\section{Discussion}

\section{Process parameters during process upset}

The CHP output decrease during the first two days of the over-acidification period was accompanied by an $\mathrm{H}_{2} \mathrm{~S}$ increase to $688 \mathrm{ppm}$ triggered by the high sulfur concentrations that were detected in the liquid phase (Table 5). The inhibition levels of $\mathrm{H}_{2} \mathrm{~S}$ were dependent on the $\mathrm{pH}$ and showed $\mathrm{IC}_{50}$ values of $250 \mathrm{ppm} \mathrm{H}_{2} \mathrm{~S}$ at $\mathrm{pH}$ 6.4-7.2 and $90 \mathrm{ppm} \mathrm{H}_{2} \mathrm{~S}$ at $\mathrm{pH}$ 7.8-8.0 [6]. Thus, the enhanced $\mathrm{H}_{2} \mathrm{~S}$ concentration probably caused the inhibition of methanogens in the primary digester due to a $\mathrm{pH}$ drop. The sulfate-reducing bacteria were apparently not affected by the altered conditions, meaning that the $\mathrm{H}_{2} \mathrm{~S}$ percentage in the biogas was increased during the time of low methanogenic activity. On the other hand, the relatively high isolated peaks of the $\mathrm{H}_{2} \mathrm{~S}$ concentration with $632 \mathrm{ppm}$ as a maximum were also detected during the first foaming period (Fig. 2). The relatively high methane concentration of almost $60 \%$ after process stabilization can be explained by the utilization of stranded VFA and, at the same time, the reduced hydrolysis gas due to the reduced organic loading rate (see also Fig. 1) and, as a result, the reduced dilution of biogas by carbon dioxide.

Neither foam formation nor nitrogen supplementation by the ANU solution had any effect on electricity production and, thus, also the biogas production (Fig. 2). The drop in CHP output before the second foaming period was not caused by any process upset, but was instead caused by the reduced loading of the CHP units, as described in the "Characteristics of the AD plant operation during the monitoring period" section. One could initially suspect that the decrease in the methane concentration after the second foaming period could be attributed to the presence of nitrate in the $\mathrm{N}$-fertilizer solution. It is generally known that some bacteria and archaea are able to use nitrate as a terminal electron acceptor in energy metabolism $[22,23]$ and, thus, nitrate reduction competes with the production of methane. Nevertheless, recent research has shown that nitrate can 
also have a positive effect on methane production at low concentrations of $0.5 \mathrm{~g} \mathrm{~L}^{-1} \mathrm{NO}_{3}-\mathrm{N}$ for $\mathrm{AD}$ of food waste [24]. In the $\mathrm{AD}$ plant described here, only $100 \mathrm{~L}$ of ANU solution was used that contained $28 \%$ nitrogen, $7 \%$ of which was $\mathrm{NO}_{3}-\mathrm{N}$. Thus, the end concentration of added $\mathrm{NO}_{3}-\mathrm{N}$ in the primary digester amounted to $4 \mathrm{mg} \mathrm{kg}^{-1}$ of fresh mass. For this reason, the negative effect of nitrate on methane concentration should be regarded as unlikely in this case. Moreover, the addition of ANU solution during the first foaming event had no apparent effect on CHP output and biogas composition (Fig. 2). It is assumed that the lowering of the TOC/TN ratio and the slight $\mathrm{pH}$ increase in the primary digester led to an improvement of the hydrolysis that was detected by the disappearance of the foam layer. The enhanced hydrolysis in turn led to the dilution of the methane concentration by hydrolysis gas.

Foam formation had no effect on the analytical data except for a slight $\mathrm{pH}$ increase after ANU addition. However, most of the wet analytical measured data changed during over-acidification of the digestate. The increase in the VFA concentration (Table 4) led to an increase of the VFA/TIC ratio and TOC content (Table 3). In addition, the concentrations of some water-soluble elements such as magnesium, calcium, manganese, phosphorus and sulfur showed an increasing tendency during over-acidification (Table 5). Elements that commonly occur as monovalent ions ( $\mathrm{K}$ and $\mathrm{Na}$ ) were not affected by over-acidification. On the other hand, some parameters such as alkalinity (Table 3 ) and substrates such as lactate (Table 4) reached their minimum values during the over-acidification phase.

The decrease in the lactate concentration is accompanied by the appearance of propionate in the VFA spectrum. Lactate is known to be an intermediate in the degradation of soluble sugars to propionic acid in $\mathrm{AD}$ [25]. With regard to the substrate mixture (Fig. 1), sugar beet is the co-substrate that supplies the $A D$ bacteria with soluble carbohydrates such as sucrose. The sugar beet loading was constant until the 108th day. As soon as propionate was no longer degraded due to disrupted methanogenesis, no more lactate was produced. After the over-acidification phase and the resumption of sugar beet feeding on day 106, lactic acid appeared in the organic acid spectrum again. At this time, the propionate concentration in the digestate had already demonstrated a decreasing tendency.

\section{Process upset indicators}

One of the indicators for over-acidification used by the biogas plant operator was the daily CHP output (Fig. 2). In the case of foaming, the digestate surface was visually checked every day.
The aim of this study was to test the known EWIs for biogas process upsets in a full-scale biogas plant. As noticed on day 95 during the period of the first process upset, the over-acidification of the $\mathrm{AD}$ process had already been in progress for a minimum of 1 week, as there had been an increase in the acetate and propionate concentrations in the previous samples (Table 4).

Kleyböcker et al. [1] introduced three EWIs for overacidification in AD processes: EWI-VFA/Ca, EWI-PO ${ }_{4} /$ $\mathrm{Ca}$ and $\mathrm{EWI}-\mathrm{PO}_{4}$. The authors developed these indicators and demonstrated their predictive ability in an $\mathrm{AD}$ system with sewage sludge and rapeseed oil as substrates $[1,26]$. As other substrates rich in carbohydrates and low in grease are used as energy crop fed to AD plants, the verification of these indicators is important for these $\mathrm{AD}$ systems. With regard to $\mathrm{VFA}_{S} / \mathrm{Ca}$, a very good predictive capability was demonstrated as this ratio showed a considerable increase by a factor of 7 between the second and third sampling period (Fig. 3a). Over the course of further over-acidification, the value continued to increase by a factor of 16 . When compared with its commonly used equivalent, VFA/TIC, the EWI-VFA/Ca value showed a clearer increasing tendency during early over-acidification; EWI-VFA/Ca increased by a factor of 15 and VFA/TIC only by a factor of 2 during the week from the 88th to the 95th day. The concentration of phosphorus, which can be observed to be proportional to the water-soluble ortho-phosphate concentration (EWI-PO4), showed a local maximum on day 102 (Fig. 3b), i.e., not before the over-acidification time. However, the absolute maximum of $54.8 \mathrm{mg} / \mathrm{L}$ was reached on day 137 . Also, EWI- $\mathrm{PO}_{4} / \mathrm{Ca}$ (here expressed as $\mathrm{P} / \mathrm{Ca}$ ) showed no clear tendency during the process upset (Fig. 3b). Thus, these two EWIs were not applicable for the process upset described here.

Extending the approach of Kleyböcker et al. [1], which used ratios of abiotic parameters as EWIs on other abiotic parameters, several other indicators for overacidification can be identified. The values of the VFA/ $\mathrm{Mg}$ ratio strongly resemble those of the VFA/Ca ratio. This is not surprising as magnesium shows similar properties to calcium in neutralizing volatile fatty acids. However, the most recognizable response during the over-acidification phase was observed for $\mathrm{VFA}_{S} / \mathrm{P}$ and $\mathrm{VFA}_{\mathrm{S}} / \mathrm{S}$. During over-acidification, these ratios increased from values below one to 240 and 260 in the case of $\mathrm{VFA}_{S} / \mathrm{P}$ and $\mathrm{VFA}_{S} / \mathrm{S}$, respectively, and fell rapidly again during the recovery phase (Fig. 3c). The rise in $V_{F A} / P$ during the first sampling week was even more intensive than that of $\mathrm{VFA}_{\mathrm{S}}$ alone.

The VFA/TIC ratio is generally used for routine checking of biogas plants [3] as this method is cheap and simple. This parameter also showed a good predictive ability for process upsets in the case of the 

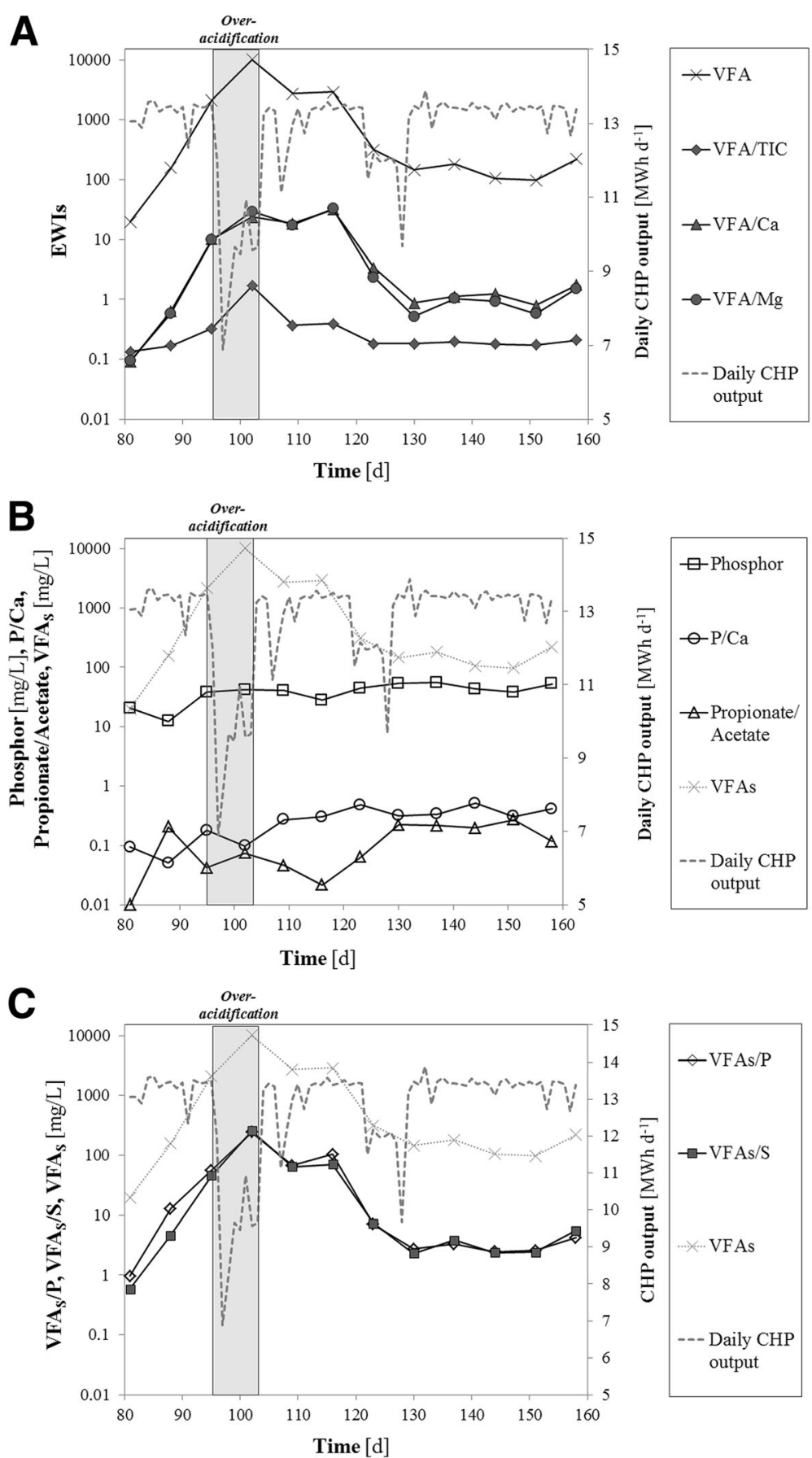

Fig. 3 Time course of ratios of wet analytical data (a) VFA/TIC, VFAs/Ca and VFAs/Mg; (b) phosphor, P/Ca and propionate/acetate; (c) VFAs/P and $V F A_{S} / S$ ) as possible EWIs for AD process upsets. For the reason of better clarity, the daily CHP-output (corresponding to the daily biogas production) and VFAs concentration is shown in all three graphics

over-acidified AD plant described in this paper, as is also shown in Table 3. Furthermore, the VFA value can be used for the calculation of VFA/P, VFA/Ca, $\mathrm{VFA} / \mathrm{Mg}$, and VFA/S, which show similar tendencies as in the case of $\mathrm{VFA}_{S} / \mathrm{P}, \mathrm{VFA}_{S} / \mathrm{Ca}, \mathrm{VFA}_{\mathrm{S}} / \mathrm{Mg}$, and $\mathrm{VFA}_{S} / \mathrm{S}$ (data not shown).
Boe et al. [16] identified the total VFA $\mathrm{S}_{\mathrm{S}}$ as well as individual volatile fatty acids as indicators of over-acidification. Both of these parameters also showed good predictive ability in the process upset described in this article. The $V_{F} A_{S}$ increased between the second and third sampling period during the over-acidification phase by a factor of 14 
and subsequently by a factor of 4.7 . In consequence, all EWIs more or less mimicked the development of the VFA concentration (Fig. 3). With regard to individual VFAs, the acetate concentration rose rapidly from the very beginning of sampling. The appearance of propionate and butyrate in the VFA spectrum during the second and third sampling week pointed to an imminent process upset. It should be noted that the sole VFA value measured by the titration method (Table 3) agreed with the $\mathrm{VFA}_{\mathrm{S}}$ measured by HPLC (Table 4) only at very high acetate concentrations.

The propionic/acetic acid ratio that was presented by Marchaim and Krause [4] as "a reliable indicator for impending failure" showed a rapid increase in the very early over-acidification phase from 0 to 0.21 (Fig. 3b). This value however decreased again very quickly during the subsequent course of $\mathrm{AD}$ due to the enormous increase in the acetate concentration. Thus, this indicator is not suitable for the process upsets described in this publication. Marchaim and Krause [4] showed that the propionic/acetic acid ratio was useful as an indicator of over-acidification after overloading an AD system with a glucose solution. As in the case of the full-scale digester described in this work, the over-acidification cause was a poisoning of the system by mycotoxines produced in the moldy substrate; thus, the reaction mechanism varied from that of Marchaim and Krause [4].

To evaluate the praxis relevance of the above mentioned EWIs, the usage of the VFA $\mathrm{V}_{S}$ was the most appropriate method for the prediction of the over-acidification. However, the analysis of VFA by the cheap titration method was not sensitive enough. The EWI-VFA/Ca showed a better predictability than its commonly used analog VFA/TIC.

Several parameters exhibited a response in the case of over-acidification. However, none of them could be used for the prediction of foam formation. Previous research has shown that the formation of foam in AD is the result of a disorder in the hydrolysis stage of the AD of organic material $[2,9]$. For this reason, none of the commonly measured parameters are suitable as EWIs for foaming because only analytes connected with the later stages of biogas production such as volatile fatty acids are observed in practice. The only parameter that was considered in the literature in association with $\mathrm{AD}$ foaming was the $\mathrm{C} / \mathrm{N}$ ratio [12]. During the first four sampling weeks, the TOC/TN ratio increased to 4.99 . However, at the time of foaming, TOC/TN already had a declining tendency, meaning that no reliable conclusions can be drawn concerning the use of the TOC/TN ratio as an indicator for foaming here. In the case of cattle rumen, high levels of potassium and low levels of sodium were associated with bloat, which is also a kind of AD foaming [27]. The sodium concentration decreased after the over-acidification phase from values of $250-270$ to
$231 \mathrm{mg} / \mathrm{L}$ during the foaming period and further decreased to $199 \mathrm{mg} / \mathrm{L}$ thereafter (Table 5). Subsequently, the sodium concentration rose again to $215 \mathrm{mg} / \mathrm{L}$ and higher values. In contrast, there was only a small local maximum of $3170 \mathrm{mg} / \mathrm{L}$ in the potassium concentration curve at the time of foaming. Nonetheless, this value was exceeded in the stable phases prior to and after the process upsets, meaning that the findings of Hall and Majak [27] cannot be applied to this case of AD foaming.

\section{Conclusions}

This study demonstrated the possibility of the prediction of over-acidification in anaerobic digestion by using several parameters. Along with the already known early warning indicators (EWIs) of VFA and VFA/Ca, the $\mathrm{VFA} / \mathrm{P}, \mathrm{VFA} / \mathrm{Mg}$, and VFA/S ratios were identified as suitable indicators for over-acidification caused by disturbed methanogenesis due to the feeding of moldy substrates. An ammonium-nitrate-urea solution that is used as a fertilizer in agriculture was found to be a suitable agent for long-term foam suppression for sugar beet codigestion in practice. The results are of great relevance due to the transfer of previous research to the practice. More research is needed to identify early warning indicators for foam formation in anaerobic digestion.

\section{Abbreviations \\ AD: Anaerobic digestion; ANU: Ammonium-nitrate-urea solution; CHP: Combined heat and power station; EWl: Early warning indicator; TIC: Alkalinity, total inorganic carbonate buffer; TN: Total nitrogen; TOC: Total organic carbon; TS: Total solids [\%]; VFA: Volatile fatty acids (determined by titration method); VFAs: Total fatty acid, a sum of acetate, propionate and butyrate concentrations; VS: Volatile solids [\% TS]}

\section{Acknowledgements}

This project was funded by the Initiating and Networking Fund of the Helmholtz Association (grant number PD-083). The authors would like to thank the operator of the affected biogas plant for the support provided. Special thanks also go to Isabell Weickardt for her support with the sample analysis.

\section{Authors' contributions}

LM collected and sorted the publication and information material, collected and analyzed the samples, and prepared the manuscript. AZ led the project, contributed with critical reading of the manuscript, and provided input for the final version. Both authors read and approved the final manuscript.

\section{Authors' information}

LM is a researcher at the Centre for Environmental Biotechnology at the Helmholtz Centre for Environmental Research GmbH-UFZ. Her research interests focus on process upsets in the anaerobic digestion as the main process of biogas production.

AZ is a senior researcher and group leader of the working group Bioprocess Engineering at the Centre for Environmental Biotechnology at the Helmholtz Centre for Environmental Research GmbH_UFZ and Professor at the University of Cooperative Education Riesa. He has more than 20 years experience working in the field of white and gray biotechnology mostly in cooperation with industry partners.

\section{Competing interests}

The authors declare that they have no competing interests.

Received: 28 April 2016 Accepted: 27 September 2016

Published online: 17 October 2016 


\section{References}

1. Kleyböcker A, Liebrich M, Verstraete W, Kraume M, Würdemann H (2012) Early warning indicators for process failure due to organic overloading by rapeseed oil in one-stage continuously stirred tank reactor, sewage sludge and waste digesters. Bioresource Technol 123:534-541. doi:10.1016/j.biortech 2012.07.089

2. Moeller L, Görsch K (2015) Foam formation in full-scale biogas plants processing biogenic waste. Energy Sustain Soc 5:1. doi:10.1186/s13705-014-0031-7

3. Lienen T, Kleyböcker A, Brehmer M, Kraume M, Moeller L, Görsch K, Würdemann H (2013) Floating layer formation, foaming, and microbial community structure change in full-scale biogas plant due to disruption of mixing and substrate overloading. Energy, Sustain Soc 3:20. doi:10.1186/ 2192-0567-3-20

4. Marchaim U, Krause K (1993) Propionic to acetic acid ratios in overloaded anaerobic digestion. Bioresource Technol 43:195-203. doi:10.1016/09608524(93)90031-6

5. Lin C-Y (1992) Effect of heavy metals on volatile fatty acid degradation in anaerobic digestion. Wat Res 26:177-183. doi:10.1016/0043-1354(92)90217-R

6. Chen Y, Cheng JJ, Creamer KS (2008) Inhibition of anaerobic digestion process: a review. Bioresource Technol 99:4044-4064. doi:10.1016/j.biortech. 2007.01.057

7. Hernandez JE, Edyvean RGJ (2008) Inhibition of biogas production and biodegradability by substituted phenolic compounds in anaerobic sludge. J Hazard Mater 160:20-28. doi:10.1016/j.jhazmat.2008.02.075

8. Kougias PG, Boe K, O-Thong S, Kristensen LA, Angelidaki I (2014) Anaerobic digestion foaming in full-scale biogas plants: a survey on causes and solutions. Water Sci Technol 69:889-895. doi:10.2166/wst.2013.792

9. Moeller L, Krieg F, Zehnsdorf A, Mueller RA (2016) How to avoid foam formation in biogas plants by coarse grain anaerobic digestion. Chem Eng Technol 39:673-679. doi:10.1002/ceat.201500300

10. Stoyanova E, Forsthuber B, Pohn S, Schwarz C, Fuchs W, Bochmann G (2014) Reducing the risk of foaming and decreasing viscosity by twostage anaerobic digestion of sugar beet pressed pulp. Biodegradation 25: 277-289. doi:10.1007/s10532-013-9659-9

11. Suhartini S, Heaven S, Banks CJ (2014) Comparison of mesophilic and thermophilic anaerobic digestion of sugar beet pulp: performance, dewaterability and foam control. Bioresource Technol 152:202-211. doi:10.1016/j.biortech.2013.11.010

12. Moeller L, Lehnig M, Schenk J, Zehnsdorf A (2015) Foam formation in biogas plants caused by anaerobic digestion of sugar beet. Bioresource Technol 178:270-277. doi:10.1016/j.biortech.2014.09.098

13. Pagilla KR, Craney KC, Kido WH (1997) Causes and effects of foaming in anaerobic sludge digesters. Water Sci Tech 36:463-470. doi:10.1016/S02731223(97)00556-8

14. Moeller L, Goersch K, Neuhaus J, Zehnsdorf A, Mueller RA (2012) Comparative review of foam formation in biogas plants and ruminant bloat. Energy Sustain Soc 2:12. doi:10.1186/2192-0567-2-12

15. Moeller L, Eismann F, Wißmann D, Nägele H-J, Zielonka S, Müller RA, Zehnsdorf A (2015) Innovative test method for the estimation of the foaming tendency of substrates for biogas plants. Waste Manage 41:39-49. doi:10.1016/j.wasman.2015.03.031

16. Boe K, Batstone DJ, Steyer J-P, Angelidaki I (2010) State indicators for monitoring the anaerobic digestion process. Water Res 44:5973-5980. doi: 10.1016/j.watres.2010.07.043

17. Zickefoose C, Hayes RB (1976) Anaerobic sludge digestion: operations manual, EPA 430/9-76-001

18. Lili M, Biró G, Sulyok E, Petis M, Borbély J, Tamás J (2011) Novel approach on the basis of FOS/TAC method. Analele Universității din Oradea, Fascicula: Protecția Mediului 17:713-718, http://protmed.uoradea.ro/facultate/anale/ protectia_mediului/2011B/im/15.\%20Mezes\%20Lili.pdf

19. Hecht C, Griehl C (2009) Investigation of the accumulation of aromatic compounds during biogas production from kitchen waste. Bioresource Technol 100:654-658. doi:10.1016/j.biortech.2008.07.034

20. Chynoweth D, Svoronos S, Lyberatos G, Harman J, Pullammanappallil P, Owens J, Peck M (1994) Real-time expert system control of anaerobic digestion. Water Sci Technol 30:21-29

21. Archer DB, Hilton MG, Adams P, Wiecko H (1986) Hydrogen as a process control index in a pilot scale anaerobic digester. Biotechnol Lett 8:197-202. doi:10.1007/BF01029380
22. Cabello P, Roldán MD, Moreno-Vivián C (2004) Nitrate reduction and the nitrogen cycle in archea. Microbiol 150:3527-3546. doi:10.1099/mic. 0.27303-0

23. Zumpft WG (1997) Cell biology and molecular basis of denitrification Microbiol Mol Biol Rev 61:533-616

24. Sheng K, Chen X, Pan J, Kloss R, Wei Y, Ying Y (2013) Effect of ammonia and nitrate on biogas production from food waste via anaerobic digestion. Biosystems Eng 116:205-212. doi:10.1016/j.biosystemseng.2013.08.005

25. Zhang B, Cai W, He P (2007) Influence of lactic acid on the two-phase anaerobic digestion of kitchen wastes. J Environm Sci 19:244-249. doi:10. 1016/S1001-0742(07)60040-0

26. Kleyböcker A, Lienen T, Liebrich M, Kasina M, Kraume M, Würdemann H (2014) Application of an early warning indicator and $\mathrm{CaO}$ to maximize the time-space-yield of a completely mixed waste digester using rape seed oil as co-substrate. Waste Manage 34:661-668. doi:10.1016/j.wasman.2013.11.01

27. Hall JW, Majak W (1989) Plant and animal factors in legume bloat. In: Cheeke PR (ed) Toxicants of plant origin, vol 3, Proteins and amino acids. CRC Press, Boca Raton, FL, USA, pp 93-106

\section{Submit your manuscript to a SpringerOpen ${ }^{\circ}$ journal and benefit from:}

- Convenient online submission

- Rigorous peer review

- Immediate publication on acceptance

- Open access: articles freely available online

- High visibility within the field

- Retaining the copyright to your article

Submit your next manuscript at $>$ springeropen.com 